\title{
DETERMINATION OF PROTEIN OXIDATION IN AQUACULTURE FEED
}

\author{
Danka M. Dragojlović ${ }^{* 1}$, Ljiljana M. Popović ${ }^{2}$, Jelena C. Čakarević ${ }^{2}$, Nedeljka J. Spasevski ${ }^{1}$, Slađana M. \\ Rakita $^{1}$, Dušica S. Čolović ${ }^{1}$, Olivera M. Đuragić ${ }^{1}$ \\ ${ }^{1}$ University of Novi Sad, Institute of Food Technology, Department of Feed Technology, 21000 Novi Sad, \\ Bulevar cara Lazara 1, Serbia \\ ${ }^{2}$ University of Novi Sad, Faculty of Technology, 21000 Novi Sad, Bulevar cara Lazara 1, Serbia
}

\begin{abstract}
This research aimed to develop a reliable, easy-to-perform and cheap method for measuring protein oxidation in complex samples such as aquaculture feed within various protein sources. For that purpose modified 2,4-dinitrophenylhydrazine (DNPH)-based method for quantification of protein carbonyls was employed whilst the modification of the method consisted of using different solutions for the extraction (distilled water and different concentrations of $\mathrm{KCl}$ and $\mathrm{NaCl}$ solutions), time of protein extraction (after homogenization and over the night) and concentration of trichloroacetic acid (10 and 25\% TCA) for protein precipitation. Extraction during the night, higher TCA concentration and the use of $0.5 \mathrm{M} \mathrm{KCl}$ extraction solution resulted in the highest protein amount measured by the Lowry method and $280 \mathrm{~nm}$ protein estimation. On the other hand, the lowest protein yield was obtained by using distilled water for the extraction. Furthermore, the lowest amount of protein carbonyls was in the case when extraction was performed with distilled water (DW), while the highest content of protein carbonyls was reached with $0.15 \mathrm{M} \mathrm{KCl}$ and $0.5 \mathrm{M} \mathrm{KCl}$ extraction solutions. It was observed that the amount of proteinbound carbonyls compounds was increasing during storage under accelerated conditions and, in comparison to the original method, the modified method for measuring protein oxidation resulted in a higher amount of carbonyls during all points of storage.
\end{abstract}

Key words: protein extraction, carbonyl content, globulin,2,4-dinitrophenylhydrazine

\section{INTRODUCTION}

Aquaculture is one of the fastest-growing industries in animal food production, due to its health benefits and as a good source of proteins for humans (Ayadi, Rosentrater \& $\mathrm{Mu}-$ thukumarappan, 2012). For the past few decades, oceans and inland waters have been fished to the limit of sustainability. Therefore, nowadays there is an increasing trend of aquaculture feed production in order to supply the future fisheries production (Huntington \& Hasan, 2009). According to statistics, the global production of aquaculture feed increased by $4 \%$ in 2018 with an estimated 40 million tons, and this industry accounts for more than a 
half of world fisheries production for human consumption (FAO, 2012). Furthermore, FAO estimates that by 2050 the demand for food will rise by $60 \%$ and between 2010 and 2050 aquaculture is expected to grow by nearly $90 \%$ (FAO, 2012). Contemporary manufactured aquaculture feed is prepared according to nutritional requirements of type and life stage of fish species (Davis, 2015). Protein sources are the most expensive ingredients in aquaculture feed, and depending on the maturity and species their content is ranging from 25 to $55 \%$ (Jobling, 2012). During technological processsing and storage of food and feed, lipid and protein oxidation can occur. Deteriorative processes that are caused by oxidation of feed and food can lead to loss of quality, destruction of nutrient content and possible formation of reactive and toxic compounds which can adversely affect the growth, health and welfare of animals (Decker, Faustman \& Lopez-Bote, 2000). As an indicator of lipid oxidation, the thiobarbituric acid reactive substances (TBARS) method is mostly used for food and feed quality control (Papastergiadis, Mubiru, Van Langenhove \& De Meulenaer, 2012; Rakita et al., 2020). However, oxidation of proteins is still not well investigated in the food and feed chain, and most previous studies have been conducted in order to investigate the involvement of protein oxidation in several human diseases (Davis, 2015; Reeg \& Grune, 2015).

During feed production and storage, aquaculture feeds are exposed to reactive oxygen species (ROS) and metal-catalyzed oxidation (MCO), which further initiate modification and oxidation of proteins (Davis, 2015). Additionally, haemoglobin is commonly used as a source of protein in aquaculture feed, which can easily be absorbed by the intestines of the animals and lipid oxidizing and metal catalysts can also initiate the reaction of protein oxidation (Chookird, Tantikitti, Pongarda \& Schrichanun, 2010; Guyon, Meynier \& de Lamballerie, 2016). Among a wide spectrum of stable and unstable products, the formation of stable carbonyl derivatives is considered as a marker of protein oxidation for various different assays (Levine \& Stadtman, 2001; Armenteros, Heinonen, Ollilainen, Toldra \& Estevez, 2009; Soglia, Petracci \& Ertbjerg, 2016). Carbonyl derivatives of proteins are produced as a result of oxidative cleavage of the peptide backbone via the $\alpha$-amidation pathway. Also, oxidation of some amino acid residues (arginine, lysine, and proline residues) results in the formation of carbonyl derivatives (Stadtmann \& Levine, 2000). Recently some advanced methods have been developed, such as measurement of the carbonyls products, $\alpha$ amino adipic (AAS) and $\gamma$-glutamic (GGS) semialdehyde, which indicate $60 \%$ of total carbonyl compounds in the food system (Estevez, Ventanas \& Heinonen, 2011; Mitra, Lametsch, Akcan \& Ruiz-Carrascal, 2018). Besides advanced methods, the principle of the wellknown 2,4-dinitrophenyl hydrazine (DNPH) method is based on derivatisation of carbonyl groups with DNPH which leads to the formation of stable protein-bound 2,4-dinitrophenylhydrazones. The absorbance of formed protein-bound 2,4-dinitrophenylhydrazones (DNP) can be measured at $370 \mathrm{~nm}$, by using the absorption coefficient of 22,000 and DNP can be quantified as the ratio of the absorbance at 370 to that at $280 \mathrm{~nm}$ (Levine et al., 1990). In comparison to the advanced methods, the DNPH method is robust, but on the other hand, it is cheap, does not demand expansive equipment and is very suitable for food products (Soglia et al., 2016).

In order to measure protein oxidation in food, recently some DNPH-based methods were developed mostly for meat products (Eymard, Baron \& Jacobsen, 2009). Protein oxidation in fish feed causes loss of nutrients with emphasis on essential amino acids as well as loss of protein digestibility, and loss of feed quality (Guyon et al., 2016). As it was already mentioned aquaculture feed is very rich in proteins (approximately 35\%), hence besides fat oxidation, it is of major importance to follow the changes on proteins as well. Therefore, the aim of the presented study was to develop a simple, low-cost and reliable method to investigate protein oxidation in complex samples such as aquaculture feed.

\section{MATERIALS AND METHODS}

$\mathrm{NaCl}, \mathrm{KCl}$ and trichloroacetic acid (TCA) were purchased from Lachner (Neratowitz, Czech Republic). Sodium dodecyl sulphate was purchased from Thermo Fisher (Kandel, Germany). Dinitrophenylhidrazine was purchased from Acros Organics (Geel, Belgium). Ethyl acetate was obtained from Panreac (Barcelona, Spain). Guanidine hydrochloride 
for molecular biology was purchased from Sigma Aldrich (St. Louis, USA) and ethanol was obtained from Reahem (Srbobran, Serbia). Extruded rainbow trout feed was purchased from a local fish feed market and used in this research. The particular fish feed manufacturer was chosen due to the various protein sources, that the rainbow trout feed contained. Fish meal, soy concentrate, wheat meal, haemoglobin, corn and gluten were the protein sources in the extruded rainbow trout feed.

\section{Preparation of oxidized rainbow trout feed}

To examine changes in the extent of protein oxidation, feed samples were stored for fifteen days under accelerated conditions in a climate chamber (Binder kbf 240, Tuttlingen, Germany) with controlled temperature, relative humidity and air circulation settings. Samples were placed in shallow glasses vessels to provide better contact with the air. The conditions were settled as follows: the temperature at $70 \pm 2{ }^{\circ} \mathrm{C}$, moisture at $45 \%$ and $100 \%$ of air circulation. Samples were collected every 5 th day and immediately frozen at $-25{ }^{\circ} \mathrm{C}$ before analysis.

\section{Sodium Dodecyl Sulfate Polyacrylamide Gel Electrophoresis (SDS-PAGE)}

The SDS-PAGE of rainbow trout feed was carried out by the method of Laemmli (1970). The system used for SDS-PAGE was consisted of stacking gel $(40 \mathrm{mg} / \mathrm{ml}$ acrylamide) and separating gel $(100 \mathrm{mg} / \mathrm{ml}$ acrylamide $) .1$ $\mathrm{mg} / \mathrm{ml}$ of sample was dissolved in tris/glycine buffer ( $\mathrm{pH}$ 6.8), which contained $20 \mathrm{~g} / \mathrm{l} \mathrm{SDS}$ (sodium dodecyl sulfate) and $50 \mathrm{~g} / \mathrm{l} \beta$-mercaptoethanol. Electrophoresis (Multi Drive XL; Pharmacia, Uppsala, Sweden) was performed at $60 \mathrm{~mA}$ and voltage was running until the tracking dye has reached the bottom of each gel. Subsequently the gel is further proceeded with $2 \mathrm{mg} / \mathrm{ml}$ Coomassie brilliant blue R-250 in a mixture of acetic acid:methanol:water (1:5:4). Afterwards destaining was performed with a mixture of $70 \mathrm{mg} / \mathrm{ml}$ of acetic acid and $60 \mathrm{ml} / \mathrm{l}$ of methanol in water for $16 \mathrm{~h}$.

\section{Protein content assays}

One $\mathrm{g}$ of the sample was extracted in $10 \mathrm{ml}$ of ice-cold distilled water or different concentrations of $\mathrm{KCl}$ and $\mathrm{NaCl}(0.15 \mathrm{M}, 0.5 \mathrm{M}$ and 1 $\mathrm{M})$. The solution was homogenized three times using Ultra-Turrax T25 basic (IKA-Werke,
Germany) at $9500 \mathrm{rpm}$ for $30 \mathrm{~s}$, and extracted during the night on ice in a refrigerator under $4^{\circ} \mathrm{C}$. The qualitative estimation of proteins was observed at $280 \mathrm{~nm}$ and quantitative analysis of proteins was carried out according to Lowry's method (Lowry, Rosenbrough, Fair \& Randall, 1951). The standard calibration curve was prepared using bovine serum albumin. All extractions were done in triplicates.

\section{Protein oxidation assay by DNPH method}

The applied method for protein carbonyls was the modification of the traditional method (Levine et al., 1990) and DNPH method for determination of protein carbonylation in muscle and meat, described by Soglia et al. (2016). In comparison with muscle and meat samples, aqua feed samples are more complex in their chemical composition, as they contain plant- and animal-based proteins, and therefore, several modifications had to be included in the procedure. The method modification was consisted of using different solutions for the extraction (distilled water, and different concentrations of $\mathrm{KCl}$ and $\mathrm{NaCl}$ ), time of protein extraction (after homogenization and during the night) and TCA concentration (10 and $25 \%$ ) for protein precipitation. Protein extracts were prepared as previously described in Protein content assays. Samples were then left in the refrigerator on ice overnight, under $4{ }^{\circ} \mathrm{C}$. Three aliquots and two blanks were taken from every solution and mixed with $1 \mathrm{ml}$ of $25 \%$ TCA and centrifuged at $12,000 \mathrm{rpm}$ for 5 minutes (Eppendorf MiniSpin Plus Centrifuge, Germany). Subsequently, $400 \mu 1$ of SDS were added to the pellet and heated at $95{ }^{\circ} \mathrm{C}$ for 10 minutes and ultrasonicated (VTUSC6, Vellman, Gavere, Belgium) at $40{ }^{\circ} \mathrm{C}$ for 30 minutes. The same procedure was repeated for blank. The solution was cooled in cold tap water and $800 \mu \mathrm{l}$ of $0.3 \%(\mathrm{w} / \mathrm{v}) \mathrm{DNPH}$ in $3 \mathrm{M}$ $\mathrm{HCl}$ were added in aliquots, while $800 \mu \mathrm{l}$ of 3 $\mathrm{M} \mathrm{HCl}$ were added in blanks. During one hour incubation (in dark) at room temperature, aliquots and blanks were vortexed every 15 minutes. After incubation, $400 \mu \mathrm{l}$ of $40 \%$ TCA were added and centrifuged $(10,000 \mathrm{rpm}, 5$ minutes) to precipitate proteins. Pellet was washed with ethanol: ethyl acetate (1:1) three times to remove unreacted DNPH and then centrifuged $(12,000 \mathrm{rpm}, 5$ minutes). Afterwards, the pellet was dissolved in $1.5 \mathrm{ml}$ of 6 $M$ guanidine hydrochloride in $20 \mathrm{mM}$ $\mathrm{NaH} 2 \mathrm{PO} 4$ (pH 6.5) and the solution was incu- 
bated during the night at $4{ }^{\circ} \mathrm{C}$, as it was described by Soglia et al. (2016). All samples were filtered through $0.45 \mu \mathrm{m}$ cellulose syringe filter. Absorbance was measured at 280 and $370 \mathrm{~nm}$ with UV-VIS 1800 spectrophotometer (Shimadzu Corporation, Japan). Carbonyl content was expressed as $\mathrm{nmol} / \mathrm{mg}$ protein using an absorption coefficient of 22000 $\mathrm{M}-1 \mathrm{~cm}-1$ and with slight modification by introducing coefficient 0.43 to remove the potential interference with hydrazone at $280 \mathrm{~nm}$ (Levine, Williams, Stadtman \& Shacter, 1994; Soglia et al., 2016).

The following equation was used for carbonyl content calculation (Soglia et al., 2016):

$$
\begin{aligned}
& \text { Carbonyls }\left(\frac{n m o l}{m g}\right)= \\
& \frac{A b s_{370}-A b s_{370}(\text { blank })}{22000 \times\left(A b s_{280}-\left(A b s_{370}-A b s_{370}(\text { blank })\right) \times 0.43\right)} \times 10^{6}
\end{aligned}
$$

\section{Statistical analysis}

One way analysis of variance (ANOVA) was used to test the influence of the methods and accelerated conditions on obtained protein carbonyl content. The differences between treatment means were assessed with the Tukey's HSD test at $p<0.05$. The data were statistically analysed using the Statistica software version 13 (Statsoft Inc. 2013, USA).

\section{RESULTS AND DISCUSSION}

\section{SDS-Page}

Gel electrophoresis was employed to observe the distribution of molecular masses of fish feed mixture (sample in duplicate) and the electrophoretic profile of the sample is shown in Figure 1. The obtained results indicated that the sample consisted of molecular weight (MW) bands ranging from 14- $66 \mathrm{kDa}$. Within this range, there were at least three major protein bands: at $\sim 24 \mathrm{kDa}, \sim 29 \mathrm{kDa}$ and $\sim 66$ $\mathrm{kDa}$ among which the $\sim 66 \mathrm{kDa}$ was the most prominent. The globulin fractions with main subunits with MW of about 29 and $66 \mathrm{kDa}$ and minor subunits below $14 \mathrm{kD}$ were dominant in the sample mixture. According to the profile of the sample, it could be said that proteins from the sample were mainly originated from the soy concentrate because globulins are the dominant protein fractions in soy concentrate and other leguminous and oilseeds (Mandal \& Mandal, 2000; Popović et al., 2017). These results are in agreement with Chen, Zhao,
Chassenieux and Nicolai (2016), who showed that soy globulins represented subunits of $\beta$ conglycinin $(\sim 66 \mathrm{kDa})$ and basic polypeptides of glycinin ( $24 \mathrm{kDa}$ and $\sim 29 \mathrm{kDa})$. Myofibrillar proteins make up 66-77\% of total proteins in fish muscle, which is a major ingredient of fish feed in the form of fish meal. Furthermore, myofibrillar proteins are composed of myosin (light chain $\sim 15 \mathrm{kDa}, \sim 18$ $\mathrm{kDa}$ and heavy chain $\sim 200 \mathrm{kDa})$, actin $(\sim 45$ $\mathrm{kDa})$ and proteins such as tropomyosin $(\sim 35$ $\mathrm{kDa})$, troponin and actinin $(\sim 102 \mathrm{kDa})$ (Porzio $\&$ Pearson, 1977). However, based on the results it can be assumed that these proteins were not dominant in the sample shown in Fig 1.

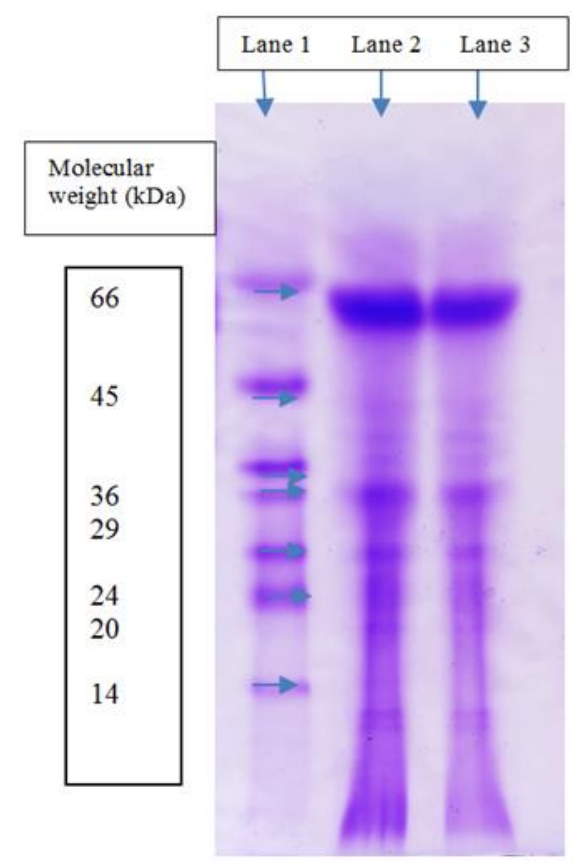

Figure 1. SDS-PAGE pattern of the rainbow trout feed. Lane 1 - molecular weight standards. Lane 2 and 3 -aquaculture feed in duplicate

\section{Protein content assay}

Considering the complexity of the rainbow trout feed sample, different extraction solutions (distilled water, $\mathrm{NaCl}$ and $\mathrm{KCl}$ ) were chosen to determine which extraction solution would give the highest possible protein yield after extraction. Rainbow trout feed contains various protein sources such as soybean meal, fish meal, wheat middlings, corn, gluten, etc. However, the highest percentage in the formulation of rainbow trout feed, among all protein sources are soybean meal and fish meal (Boyd \& Polioudakis, 2016). Albumins and globulins are mostly present in oilseed and legumes, such as soybean (Mandal \& Mandal, 
2000). Furthermore, according to their water solubility fish proteins can be divided into three groups: myofibrillar proteins (soluble in high and low ionic saline solutions), sarcoplasmic proteins (completely soluble in water) and stroma proteins (insoluble in water) (Phillips \& Williams, 2011). Since most fish meal and soybean meal proteins are watersoluble and ionic saline soluble, distilled water and different concentration of $\mathrm{NaCl}$ and $\mathrm{KCl}$ solutions were employed to obtain higher protein solubilisation during extraction. Qualitative results were observed with $280 \mathrm{~nm}$ protein estimation, where the highest protein amount was found in extract when $0.5 \mathrm{M} \mathrm{KCl}$ solution was employed for extraction (Fig. 2). However, other extraction solutions did not differ significantly $(p>0.05)$ in protein content estimated at $280 \mathrm{~nm}$. Absorbance measured at $280 \mathrm{~nm}$ varied from 0.33 for extraction with $0.5 \mathrm{M} \mathrm{NaCl}$ to 0.80 for extraction with $0.5 \mathrm{M}$ $\mathrm{KCl}$. This confirms that extraction with DW and $0.5 \mathrm{M} \mathrm{NaCl}$ which gave the lowest absorbance reading enabled the lowest protein yield (measured by Lowry), whereas, the extraction with $0.5 \mathrm{M} \mathrm{KCl}$ provided the highest absorbance reading and gave the highest protein yield in the extract. At low salt concentration, electrostatic forces, in general, improve protein solubility, which can conse- quently affect an increase in protein yield. On the other hand, in the cases where concentration is above $0.5 \mathrm{M}$, further salt addition can lead to the precipitation of proteins and reduction of protein solubility (known as Hofmeister effects), and hence impair protein extraction (Weingärtner, Cabrele \& Herrmann, 2012).

Figure 3 shows protein content in extracts obtained with different extraction solutions. The protein concentration determined by Lowry's method in different extracts was in the range of 54 to $80 \mathrm{mg} / \mathrm{ml}$. The highest concentration of protein was observed in the extract obtained by using $0.5 \mathrm{M} \mathrm{KCl}$. In comparison to the extraction with DW, the extraction with 0.5 $\mathrm{M} \mathrm{KCl}$ resulted in the approximately $48 \%$ higher amount of proteins from feed that are soluble in extraction trout feed. The concentration of $\mathrm{NaCl}$ in the range tested did not affect protein solubilisation. Although data regarding protein determination by the Lowry method in aquaculture feed are rather scarce, the Lowry method has been used for protein determination of fish, wheat, soy and corn samples, which aquaculture feed sample is mainly consisted of (Hu et al., 2010; Jin, Liu, Zheng, Wang \& He, 2016; Mæhre, Dalheim, Edvinsen, Elvevoll \& Jensen; 2018).

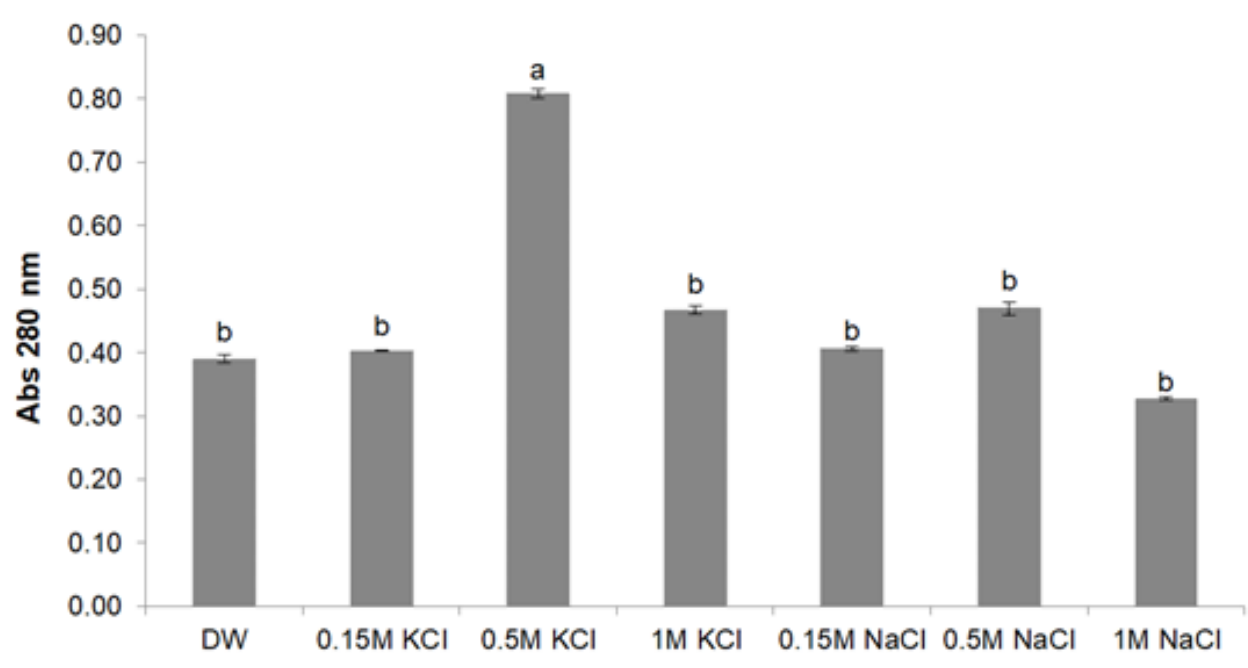

Figure 2. Protein estimation at $280 \mathrm{~nm}$ in different solutions (DW-distilled water, different concentration of $\mathrm{KCl}$ and $\mathrm{NaCl}$ solution). The values are expressed as means \pm S.D; $\mathrm{a}-\mathrm{b}$ means having different superscripts differ $(\mathrm{p}<0.05)$ between extraction solutions 


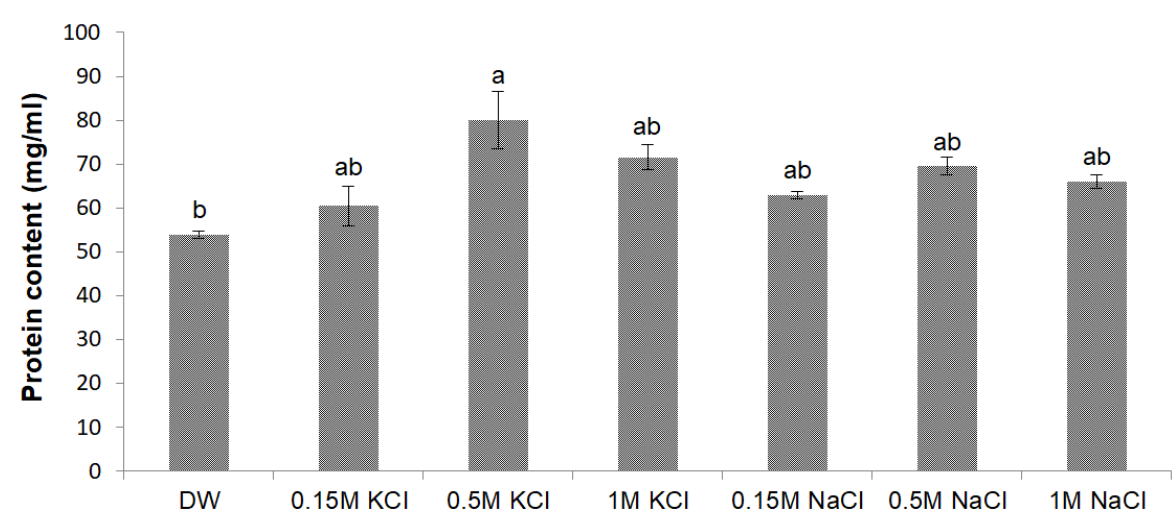

Figure 3. Protein content in different solutions (DW-distilled water, different concentration of $\mathrm{KCl}$ and $\mathrm{NaCl}$ solution). The values are expressed as means \pm S.D.; $a-b$ means having different superscripts differ $(p<0.05)$ between extraction solutions

Table 1.

Carbonyls amount obtained by using different extraction solutions

\begin{tabular}{lc}
\hline Solvents & $\begin{array}{c}\text { Carbonyls } \\
\text { (nmol/mg of protein) }\end{array}$ \\
\hline $\mathrm{DW}$ & $2.63 \pm 0.74^{\mathrm{c}}$ \\
$0.15 \mathrm{M} \mathrm{KCl}$ & $7.91 \pm 0.28^{\mathrm{a}}$ \\
$0.5 \mathrm{M} \mathrm{KCl}$ & $7.96 \pm 0.11^{\mathrm{a}}$ \\
$1 \mathrm{M} \mathrm{KCl}$ & $5.26 \pm 0.47^{\mathrm{b}}$ \\
$0.15 \mathrm{M} \mathrm{NaCl}$ & $4.58 \pm 0.63^{\mathrm{b}}$ \\
$0.5 \mathrm{M} \mathrm{NaCl}$ & $4.36 \pm 0.87^{\mathrm{b}}$ \\
$1 \mathrm{M} \mathrm{NaCl}$ & $3.73 \pm 0.51^{\mathrm{bc}}$ \\
\hline $\begin{array}{l}\text { Results are shown as mean value }(n=9) \pm S . D \\
a-b\end{array}$ Means having different superscripts differ $(p<0.05)$ between extraction solutions &
\end{tabular}

\section{Determination of protein oxidation by modified DNPH method}

Protein-bound carbonyls content in extruded rainbow trout feed measured by modified DNPH method is presented in Table 1.

As shown, the content of carbonyls was in the range of 2.63 to $7.96 \mathrm{nmol} / \mathrm{mg}$ protein. Similarly to the results conducted by the Lowry method, the lowest amount of protein carbonyls was observed in the case when extraction was performed with DW. In comparison to extraction with $\mathrm{DW}$, the use of 0.15 $\mathrm{NaCl}, 0.5 \mathrm{M} \mathrm{NaCl}$ and $1 \mathrm{M} \mathrm{KCl}$ as extraction solvents caused a significant increase $(p>0.05)$ in the number of protein carbonyls. Precisely, the use of these solvents resulted in twofold higher carbonyls amount than using DW. Additionally, the highest amounts of protein carbonyls $(7.91$ and $7.96 \mathrm{nmol} / \mathrm{mg}$ protein, respectively) were reached in the case where 0.15 $\mathrm{M} \mathrm{KCl}$ and $0.5 \mathrm{M} \mathrm{KCl}$ were used as solvents for protein extraction. Compared to extraction with DW, the extraction with $0.15 \mathrm{M} \mathrm{KCl}$ and
$0.5 \mathrm{M} \mathrm{KCl}$ resulted in the detection of a threefold higher amount content of carbonyls in rainbow trout feed. These results are also in agreement with protein estimation on $280 \mathrm{~nm}$ and protein content determined by the Lowry method, where the highest protein amount was by using $0.5 \mathrm{M} \mathrm{KCl}$. This was expected because low salt solutions caused increased protein solubility. As a consequence, more protein was extracted and therefore more carbonyls content was determined.

In order to validate the ability of the modified method to yield an estimated increasing content of carbonyls, the original method (without modifications) described by Soglia et al. (2016) and the modified one were applied on oxidized rainbow trout feed sample and compared. Protein oxidation was induced by accelerated storage conditions for fifteen days. The comparison of the two methods is presented in Figure 4. The results showed that the amounts of carbonyls compounds were increasing during the time in the climate cham- 
ber under accelerated conditions. By using the modified method, the carbonyls content varied between 3.83 and $5.43 \mathrm{nmol} / \mathrm{mg}$ protein during the first ten days of storage but did not significantly ( $p>0.05)$ change. However, a significant increase $(p<0.05)$ in the content of carbonyls was achieved on the 15th day of storage, reaching the highest level of 13.79 $\mathrm{nmol} / \mathrm{mg}$ protein. These results are expected because higher temperature leads to intense protein oxidation, cleavage of the peptide backbone and hence more carbonyls generation (Traore et al., 2012). The increase in carbonyl content might be explained by the fact that fish meal and soybean concentrate are rich in lysine whose oxidation leads to the formation of carbonyl derivatives. Applied high temperature could also cause lipid peroxidation of the fat in the sample since aqua feed is high in fat content. Consequently, the reaction of aldehyde groups of the lipid peroxidation product (malondialdehyde) with lysine $\alpha$-amino groups of proteins might result in a Schiff base which has a carbonyl function as well (Levine \& Stadtman, 2001). Furthermore, fish feed is rich in haemoglobin, which is well known as an endogenous factor for protein oxidant formation (Davis, 2015). Additionally, highly reactive species such as hydroxyl radical, which can arise in fish feed during lipid oxidation or as a product of metal ion catalysed decomposition of $\mathrm{H} 2 \mathrm{O} 2$ can accelerate protein oxidation (Requena, Levine \& Stadtman, 2003).

In comparison to the modified method, results obtained by using the original method showed a lower amount of carbonyls during all points of storage (ranging from 1.14 to $3.64 \mathrm{nmol} / \mathrm{mg}$ protein). The number of carbonyl compounds was increased during the first ten days under accelerated conditions, reaching the highest content of $3.64 \mathrm{nmol} / \mathrm{mg}$ protein. On the 15 th day of storage, carbonyl content significantly $(\mathrm{p}<0.05)$ decreased to $1.14 \mathrm{nmol} / \mathrm{mg}$ protein. It can be assumed that thermal treatment of proteins leads to a decrease in the protein solubility, as a reaction of protein structural changes such as agglomeration, polymerization and inter-and intra-molecular cross-linking (Lund, Lametsch, Hviid, Jensen \& Skibsted, 2007).

Generally, significantly $(\mathrm{p}<0.05)$ higher carbonyls concentration was measured with the modified method in the oxidized rainbow trout feed in fresh ( 0 days) and after 15 days of accelerated conditions. On the 15th day of storage, the modified method resulted in approximately twelve times higher concentrations of carbonyls in comparison with the original method.

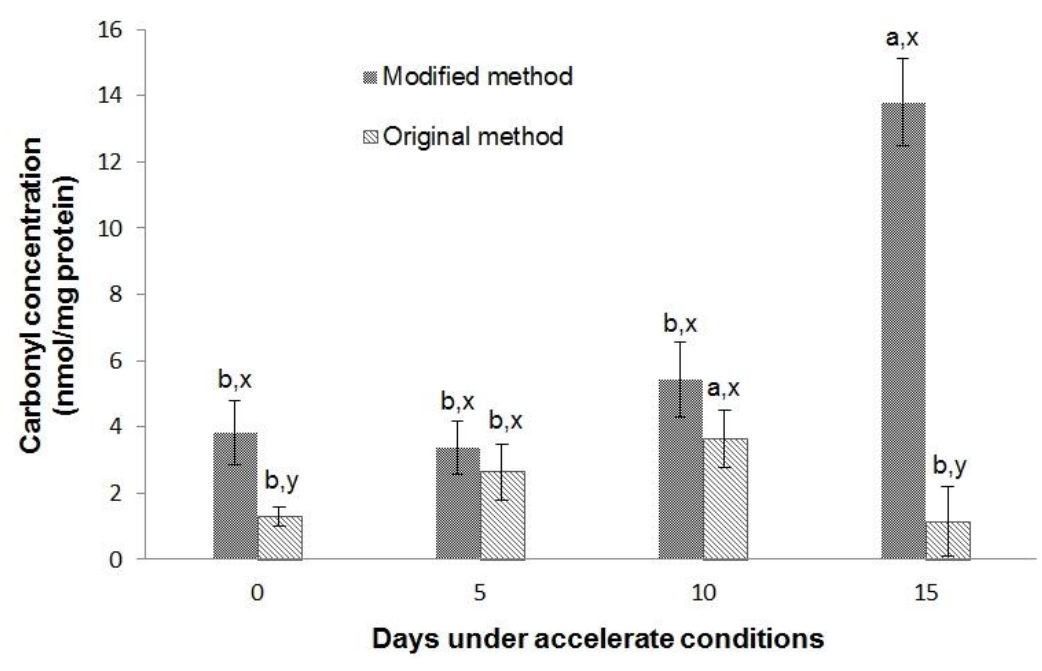

Figure 4. Changes in carbonyl concentration during storage under accelerate conditions. Results are shown as mean value $(\mathrm{n}=9) \pm$ standard deviation; ${ }^{\mathrm{a}-\mathrm{b}}$ means having different superscripts differ $(\mathrm{p}<0.05)$ between different days under accelerate conditions. ${ }^{\mathrm{x}, \mathrm{y}}$ Means having different superscripts differ $(\mathrm{p}<0.05)$ between modified DNPH and original method by Soglia et al. (2016) 
It can be assumed that conditions of protein extraction (such as time of extraction and ionic strength solution of $\mathrm{KCl}$ ) applied in the original method may not have been adequate to yield a higher amount of carbonyls from aquaculture feed proteins as was the case with the modified method.

\section{CONCLUSIONS}

The presented modified DNPH-based method showed to be suitable for the determination of protein oxidation of aquaculture feed samples, which are composed of manly of $24 \mathrm{kDa}, 29$ $\mathrm{kDa}$ and $66 \mathrm{kDa}$ protein fractions. The results indicated that a long time of protein extraction, higher TCA concentration for protein precipitation, and higher ionic strength of extraction solution $(0.5 \mathrm{M} \mathrm{KCl})$ resulted in the highest protein content and the highest amount of carbonyls $(7.96 \mathrm{nmol} / \mathrm{mg}$ protein) in the aqua feed sample. These extraction conditions improved protein solubility and therefore affected an increase in the concentration of carbonyls. On the other hand, the lowest protein yield and carbonyl concentration were obtained when distilled water was used as an extraction solvent. When oxidation of aqua feed under accelerated storage conditions was tested, carbonyl content increased in the feed sample after fifteen days of storage. The modifications employed in the modified method resulted in twelvefold more carbonyl concentration than in the original method appeared to be more suitable aqua feed samples that contain plant- and animal-based proteins and are more complex in chemical composition.

\section{ACKNOWLEDGEMENTS}

This work was financed by the Ministry of Education, Science and Technological Development, Republic of Serbia (Grant No. 45103-9/2021-14/200222).

\section{REFERENCES}

Armenteros, M., Heinonen, M., Ollilainen, V., Toldrá, F., \& Estevez, M. (2009). Analysis of protein carbonyls in meat products by using the DNPHmethod, fluorescence spectroscopy and liquid chromatography-electrospray ionisation-mass spectrometry (LC-ESI-MS). Meat Science, 83(1), 104-112.

https://doi.org/10.1016/j.meatsci.2009.04.007

Ayadi, F. Y., Rosentrater, K, A., \& Muthukumarappan, K. (2012). Alternative protein sources for aquaculture feeds. Journal of Aquaculture Feed Science and Nutrition, 4(1), 1-26.
Boyd, C. E., \& Polioudakis, M. (2006, April 1). Land use for aquaculture production. Retrieved from Global Aquaculture Advocate. https://www.aquaculturealliance.org/advocate/landuse-for-aquaculture-production

Chen, N., Zhao, M., Chassenieux, C., \& Nicolai, T. (2016). Data on the characterization of native soy globulin by SDS-Page, light scattering and titration. Data in Brief, 9, 749-752. http://dx.doi.org/10.1016/j.foodhyd.2015.12.028

Chookird, D., Tantikitti, C., Pongdara, A., \& Srichanun, M. (2010). Effect of hemoglobin powder substituted for fishmeal on growth performance, protein digestibility, and trypsin gene expression in Litopenaeusvannamei. Songklanakarin Journal of Science \& Technology, 32(2), 119-127. http://rdo.psu.ac.th/sjst/journal/32-2/0125-3395-322-119-127.pdf

Davis, D. A. (2015). Feed and feeding practices in aquaculture ( $1^{\text {st }}$ ed., pp 128-150). Cambridge, UK: Woodhead Publishing.

Decker, E. A., Faustman, C., \& Lopez-Bote, C. J. (2000). Antioxidants in muscle foods: nutritional strategies to improve quality $\left(1^{\text {st }}\right.$ edition ). New York, USA: John Wiley \& Sons.

Estévez, M., Ventanas, S., \& Heinonen, M. (2011). Formation of Strecker aldehydes between protein carbonyls- $\alpha$-aminoadipic and $\gamma$-glutamic semialdehydes-and leucine and isoleucine. Food Chemistry, 128(4), 1051-1057. https://doi.org/10.1016/j.foodchem.2011.04.012

Eymard, S., Baron, C. P., \& Jacobsen, C. (2009). Oxidation of lipid and protein in horse mackerel (Trachurustrachurus) mince and washed minces during processing and storage. Food Chemistry, 114(1), 57-65.

https://doi.org/10.1016/j.foodchem.2008.09.030

(FAO) Food and Agricultural Organization. (2012). State of Food and Agriculture 2012: Investing in Agriculture for a Better Future.

https://www.fao.org/publications/sofa/2012/en/

Guyon, C., Meynier, A., \& de Lamballerie, M. (2016). Protein and lipid oxidation in meat: A review with emphasis on high-pressure treatments. Trends in Food Science \& Technology, 50, 131-143. https://doi.org/10.1016/j.tifs.2016.01.026

Hu, X. Z., Cheng, Y. Q., Fan, J. F., Lu, Z. H., Yamaki, K., \& Li, L. T. (2010). Effects of drying method on physicochemical and functional properties of soy protein isolates. Journal of Food Processing and Preservation, 34(3), 520-540. https://doi.org/10.1111/j.1745-4549.2008.00357.x

Huntington, T. C., \& Hasan, M. R. (2009). Fish as feed inputs for aquaculture-practices, sustainability and implications: a global synthesis. FAO Fisheries and Aquaculture Technical Paper, 518, 1-61. http://www.fao.org/3/i1140e/i1140e01.pdf

Jin, D. X., Liu, X. L., Zheng, X. Q., Wang, X. J., \& He, J. F. (2016). Preparation of antioxidative corn protein hydrolysates, purification and evaluation of three novel corn antioxidant peptides. Food Chemistry, 204, 427-436. https://doi.org/10.1016/j.foodchem.2016.02.119

Jobling, M. (2012). National Research Council (NRC): Nutrient requirements of fish and shrimp. Aquaculture International, 20, 601-602. 
https://doi.org/10.1007/s10499-011-9480-6.

Laemmli, U.K. (1970). Cleavage of structural proteins during the assembly of head of bacteriophage T4. Nature, 227, 680-685.

https://doi.org/10.1038/227680a0

Levine, R. L., Garland, D., Oliver, C. N., Amici, A., Climent, I., Lenz, A., Ahn, B., Shaltiel, S., \& Stadtman, E. R. (1990). Determination of carbonyl content in oxidatively modified proteins. Methods Enzymology, 186, 464-478. https://doi.org/10.1016/0076-6879(90)86141-H

Levine, R. L., \& Stadtman, E. R. (2001).Oxidative modification of proteins during aging. Experimental Gerontology, 36(9), 1495-1502. https://doi.org/10.1016/S0531-5565(01)00135-8

Levine, R. L., Williams, J. A., Stadtman, E. P., \& Shacter, E. (1994). Carbonyl assays for determination of oxidatively modified proteins. Methods in Enzymology, 233, 346-357.

https://doi.org/10.1016/S0076-6879(94)33040-9

Lowry, O., Rosenbrough, N., Fair, A., \& Randall, R. (1951). Protein measurement with the Folin phenol reagent. Journal of Biological Chemistry, 193, 265275.

https://www.cabdirect.org/cabdirect/abstract/19511 404458

Lund, M. N., Lametsch, R., Hviid, M. S., Jensen, O. N., \& Skibsted, L. H. (2007). High-oxygen packaging atmosphere influences protein oxidation and tenderness of porcine longissimus dorsi during chill storage. Meat Science, 77(3), 295-303. https://doi.org/10.1016/j.meatsci.2007.03.016

Mandal, S., \& Mandal, R. K. (2000). Seed storage proteins and approaches for improvement of their nutritional quality by genetic engineering. Current Science, 79(5), 576-587. https://www.jstor.org/stable/24105073

Mæhre, H. K., Dalheim, L., Edvinsen, G. K., Elvevoll, E. O., \& Jensen, I. J. (2018). Protein determinationmethod matters. Foods, 7(1), 5. https://doi.org/10.3390/foods7010005

Mitra, B., Lametsch, R., Akcan, T., \& Ruiz-Carrascal, J. (2018). Pork proteins oxidative modifications under the influence of varied time-temperature thermal treatments: A chemical and redox proteomics assessment. Meat Science, 140, 134-144. https://doi.org/10.1016/j.meatsci.2018.03.011

Papastergiadis, A., Mubiru, E., Van Langenhove, H., \& De Meulenaer, B. (2012). Malondialdehyde measurement in oxidized foods: evaluation of the spectrophotometric thiobarbituric acid reactive substances (TBARS) test in various food. Journal of Agriculture and Food Chemistry, 60, 9589-9594. https://doi.org/10.1021/jf302451c
Phillips, G. O., \& Williams, P. A. (Eds.). (2011). Handbook of food proteins. Cambridge, UK: Woodhead Publishing.

Popović, Lj., Stolić, Ž., Čakarević, J., Torbica, A., Tomić, J., \& Šijački, M. (2017). Biologically active digests from pumpkin oil cake protein: effect of crosslinking by transglutaminase. Journal of the American Oil Chemists Society, 94, 1245-1251. https://doi.org/10.1007/s11746-017-3041-8

Porzio, M. A., \& Pearson, A. M. (1977). Improved resolution of myofibrillar proteins with sodium dodecyl sulfate-polyacrylamide gel electrophoresis. Biochimica et Biophysica Acta (BBA)-Protein Structure, 490(1), 27-34. https://doi.org/10.1016/0005-2795(77)90102-7

Rakita, S., Čolović, D., Levart, A., Banjac, V., Čolović, R., Dragojlović, D., \& Đuragić, O. (2020). A rapid spectrophotometric method for determination of thiobarbituric acid reactive substances in rainbow trout feed. Food and Feed Research, 47(1), 43-54. http://scindeks.ceon.rs/article. aspx $?$ artid=221753692001043R

Recreational Fisheries FAO (2012). Technical Guidelines for Responsible Fisheries 13. Food and Agriculture Organization of the United Nations. Rome, Italy. http://www.fao.org/docrep/016/i2708e/i2708e00.ht $\mathrm{m}$

Reeg, S., \& Grune, T. (2015). Protein oxidation in aging: does it play a role in aging progression? Antioxidants \& Redox Signaling, 23(3), 239-255. https://doi.org/10.1089/ars.2014.6062

Requena, J. R., Levine, R. L., \& Stadtman, E. R. (2003). Recent advances in the analysis of oxidized proteins. Amino Acids, 25(3-4), 221-226. https://doi.org/10.1007/s00726-003-0012-1

Soglia, F., Petracci, M., \& Ertbjerg, P. (2016). Novel DNPH-based method for determination of protein carbonylation in muscle and meat. Food Chemistry, 197, 670-675. https://doi.org/10.1016/j.foodchem.2015.11.038

Stadman, E. R., \& Levine, R. L. (2000). Protein oxidation. Annals New York Academy of Sciences, 899(1), 191-208. https://doi.org/10.1111/j.1749-6632.2000.tb06187.x

Traore, S., Aubry, L., Gatellier, P., Przybylski, W., Jaworska, D., Kajak-Siemaszko, K., \& SantéLhoutellier, V. (2012). Effect of heat treatment on protein oxidation in pig meat. Meat Science, 91(1), 14-21. https://doi.org/10.1016/j.meatsci.2011.11.037

Weingärtner, H., Cabrele, C., \& Herrmann, C. (2012). How ionic liquids can help to stabilize native proteins. Physical Chemistry Chemical Physics, 14(2), 415-426. https://doi.org/10.1007/s00726-003-0012-1 


\section{ODREĐIVANJE OKSIDACIJE PROTEINA U HRANI ZA RIBE}

Danka M. Dragojlović ${ }^{* 1}$, Ljiljana M. Popović ${ }^{2}$, Jelena C. Čakarević ${ }^{2}$, Nedeljka J. Spasevski ${ }^{1}$, Slađana M. Rakita $^{1}$, Dušica S. Čolović ${ }^{1}$, Olivera M. Đuragić ${ }^{1}$

${ }^{1}$ Univerzitet u Novom Sadu, Naučni institut za prehrambene tehnologije u Novom Sadu, 21000 Novi Sad, Bulevar cara Lazara 1, Srbija

${ }^{2}$ Univerzitet u Novom Sadu,Tehnološki fakultet, Bulevar cara Lazara 1, 21000 Novi Sad, Srbija

Sažetak: Cilj ovog istraživanja bilo je razvijanje pouzdane, jednostavnije, jeftinije metode za merenje oksidacije proteina u složenim uzorcima, kao što je hrana za ribe, koja u svom sastavu sadrži različite izvore proteina. U tu svrhu korišćena je modifikovana metoda za kvantifikaciju proteinskih karbonila, koja je zasnovana na 2,4dinitrofenilhidrazin (DNPH)-metodi. Modifikacija metode se sastojala u promeni rastvarača (destilovana voda različite koncentracije rastvora $\mathrm{NaCl}$ i $\mathrm{KCl}$ ) i vremenu ekstrakcije (nakon homogenizacije i preko noći), kao i koncentracije trihlor sirćetne kiseline (TCA, 10 i $25 \%$ ) za precipitaciju proteina. Uočeno je da produženo vreme ekstrakcije (tokom noći), veća koncetracija TCA (25\%) i 0,5 M rastvor $\mathrm{KCl}$-a dovodi do povećanja koncentracije proteina. S druge strane, najmanja količina proteina dobijena je ekstrakcijom pomoću destilovane vode. U pogledu količine proteinskih karbonila, pokazano je da je najveći sadržaj postignut ekstrakcijom pomoću $0,15 \mathrm{M}$ i $0,5 \mathrm{M} \mathrm{KCl}$. Tokom skladištenja uzoraka, pod ekstremnim uslovima, uočeno je da se količina karbonilnih jedinjenja povećava. A u poređenju sa originalnom metodom, modifikovanom metodom za merenje oksidacije proteina izmerena je veća količina karbonilnih jedinjenja u svakoj fazi skladištenja.

Ključne reči: ekstrakcija proteina, karbonilna jedinjenja, globulini, 2,4dinitrofenilhidrazin

Received: 2 November 2021 / Received in revised form: 2 December 2021 / Accepted: 8 December 2021

Available online: December 2021

This is an open-access article under the CC BY license (http://creativecommons.org/licenses/by/3.0). 